
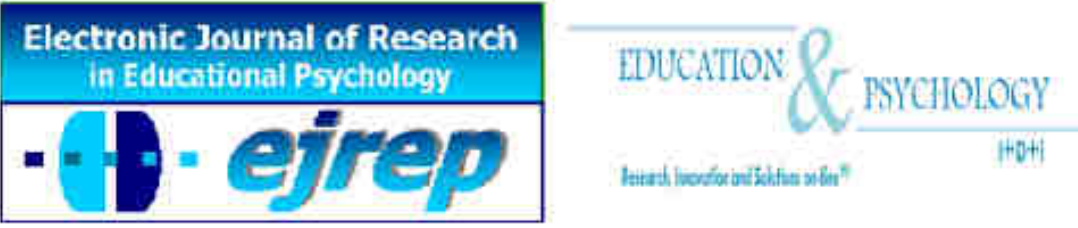

\title{
Teacher motivation, work satisfaction, and positive psychological capital: A literature review
}

\section{João Viseu ${ }^{1}$, Saul Neves de Jesus ${ }^{2}$, Claudia Rus ${ }^{3}$, \& José M. Canavarro $^{4}$}

${ }^{1}$ Research Centre for Spatial and Organizational Dynamics, University of Algarve, Faro

${ }^{2}$ Research Centre for Spatial and Organizational Dynamics, University of Algarve, Faro

${ }^{3}$ Department of Psychology, Babes-Bolyai University, Cluj-Napoca

${ }^{4}$ Faculty of Psychology and Education Sciences, University of Coimbra, Coimbra

\section{Portugal/Romania}

Correspondence: João Nuno Ribeiro Viseu. Research Centre for Spatial and Orgnaizational Dynamics, University of Algarve, Campus de Gambelas - Building 9, 8005-139 Faro, Portugal. E-mail: joaonrviseu@gmail.com

(C) Education \& Psychology I+D+i and Ilustre Colegio Oficial dela Psicología de Andaluacía Oriental

\section{Abstract}


Teacher motivation is vital for the educational system. For teachers to be motivated their work satisfaction and positive psychological capital are crucial. The state-of-the-art on teacher motivation requires a literature review regarding the studies that relate teacher motivation and the abovementioned constructs. In this paper, through electronic databases, the published studies between 1990-2014 about these issues were identified. A total of 43 studies were obtained. The main conclusions were the following: (a) 2012 was the year with more publications ( $n=7 ; 16.28 \%)$; (b) quantitative methodologies $(n=40 ; 93.02 \%)$ and self-report questionnaires ( $n=43 ; 89.59 \%)$ were the dominant methodology and instrument type; and (c) work satisfaction was the most studied concept with teacher motivation $(n=42 ; 97.67 \%)$. Our results underline the importance of work satisfaction on teacher motivation and emphasize the need to realize more studies on the relationship between teacher motivation and positive psychological capital.

Keywords: literature review, positive psychological capital, teacher motivation, work satisfaction 


\section{Motivación docente, satisfacción en el trabajo y capital psicológico positivo: una revisión}

\section{Resumen}

La motivación docente es vital para el sistema educativo. Para que los profesores estén motivados, su satisfacción laboral y el capital psicológico positivo son cruciales. El estado del arte de la motivación docente necesita una revisión de la literatura sobre los estudios que relacionen la motivación de los profesores y los constructos mencionados. En este artículo, a través de bases de datos electrónicas, se identificaron los estudios publicados sobre estos temas entre 1990-2014. Se encontró un total de 43 estudios empíricos. Las conclusiones principales fueron las siguientes: (a) 2012 fue el año con más publicaciones $(n=7 ; 16.28 \%$ ); (b) la metodología cuantitativa $(n=40 ; 93.02 \%)$ y los cuestionarios auto-cumplimentados $(n=43$; $89.59 \%$ ) fueron la metodología y tipo de instrumentos predominantes; y (c) la satisfacción laboral fue el concepto más estudiado con la motivación docente $(n=42 ; 97.67 \%)$. Nuestros resultados apuntan a la importancia de la satisfacción laboral para la motivación docente y enfatizan la necesidad de realizar más estudios sobre la relación entre la motivación docente y el capital psicológico positivo.

Palabras Clave: revisión de la literatura, capital psicológico positivo, motivación docente, satisfacción laboral 


\section{Introduction}

Work motivation is one of the most important constructs in psychology, being largely studied by academics and practitioners (Gomes \& Borba, 2011). According to Gomes and Borba (2011), this construct is present in all work contexts, for example in education. In this context, one concept - teacher motivation - is a decisive factor for school success (Jesus \& Lens, 2005). Several studies (e.g., Cardelle-Elawar, Irwin, \& Lizarraga, 2007; Santisi, Magnano, Hichy, \& Ramaci, 2014) underlined that this concept is crucial for student motivation and school functioning. A review of Jesus (2003), on this subject, evidenced that the majority of studies did not present a solid theoretical approach and the main addressed topics were the salary incentives, premises also corroborated by the work of Mueller and Hanfstingl (2010). In turn, Addison and Brundrett (2008) argued that teacher motivation is undervalued, in terms of research, comparatively to student motivation. Despite this situation, numerous aspects point to the importance of teacher motivation. Teachers have great influence on student motivation, especially because of the: (a) quality of teaching; (b) student performance; (c) class well-being; (d) improvement of students' self-efficacy beliefs; and (e) development of the teacher-student relationship (Santisi et al., 2014). In terms of school functioning, teachers are crucial in the implementation of educational policies (Jesus, 1996). In sum, teachers are fundamental in classroom and school management. Thus, it is important to address the constraints that affect these professionals and contribute to their demotivation.

A meta-analysis of Aloe, Shisler, Norris, Nickerson, and Rinker (2014) demonstrated that the incidence of burnout in teachers is high and considered as an international problem. A study of Jesus (2003) emphasized that teaching, in comparison with other occupations, presented higher distress levels. The emergence of malaise factors is related with several aspects, such as: (a) student misbehavior; (b) high workload; (c) relationship with school staff; (d) work intensity; and (e) extended work schedule (Aloe et al., 2014; Yu, Wang, Zhai, Dai, \& Yang, 2014). These aspects have contributed to an increase of turnover rates, an indicator of demotivation. Jesus (1996) registered that in Portugal more than 50 percent of teachers desired to leave their profession, in 2011 Jesus and colleagues obtained analogous results in two different samples of teachers (Brazilian and Portuguese). Lambert and McCarthy (2006) found, in the United States of America, that the majority of teachers abandoned their profession after the first five years of work. A report of the Organisation for Economic Co-operation and Development (OECD) (2005) registered similar results. 
Given the variety of work-related aspects that affect teachers and the malaise factors that emerge from these situations, it is crucial to elaborate a review on the studies about teacher motivation. Previous works (e.g., Aloe et al., 2014; Jesus, 2003) focused on variables related to the teacher itself (e.g., distress and burnout). However, few studies have addressed the influence of work attitudes and positive psychology constructs on teacher motivation, essential aspects in the promotion of work motivation. To accomplish this goal two variables were selected, work satisfaction and positive psychological capital (PsyCap).

Judge and Kammeyer-Mueller (2012) verified that work satisfaction is a fundamental construct for organizations, being defined as an evaluative process regarding one's working conditions and the profession itself. Several authors (e.g., Dalal, Baysinger, Brummel, \& LeBreton, 2012) affirmed that work satisfaction is the most important indicator of an individual's posture in a work context and is closely related with work motivation. Vieira and Jesus (2007) underlined that in teaching work satisfaction is a predictor of professional motivation. According to Hongying (2007), the satisfaction of teachers is based on the tasks performed and work environment, satisfied teachers present greater enthusiasm and psychological health. From the factors that promote satisfaction, interpersonal relations with managers and colleagues, and the work itself assume a significant relevance, in opposition salary issues, lack of professional development opportunities, work conditions, student behavior, and work-related stressors (e.g., extended schedule and work load) cause teacher dissatisfaction (Hongying, 2007). Furthermore, satisfied teachers are also more motivated, thus contributing to a better classroom and school functioning, which will facilitate the achievement of schools' objectives (Vieira \& Jesus, 2007). Due to the importance of this relationship, it is essential to analyze the studies that relate teacher work motivation and satisfaction.

Compared to physical, structural, and financial resources, employees as human resources cannot be replicated (Luthans, Youssef-Morgan, \& Avolio, 2015). Thus, human resources constitute a valuable form of capital to the organizations they belong to (Bakker \& Schaufeli, 2008). There are several forms of capital and while human and social capital are widely recognized and studied, psychological capital was given less attention (Larson \& Luthans, 2006). To distinguish between the positive organizational behavior field (POB) and other scientific positive approaches, several authors (e.g., Luthans et al., 2015) have proposed four essential criteria that must be met for a concept to be included in this approach: 
(a) possess a solid theory and research; (b) have a relative uniqueness in the organizational behavior area; (c) to be state-like; and (d) have a positive impact on work performance. Considering these criteria, Luthans, Youssef, and Avolio (2007) advanced that the positive psychological capital constructs, self-efficacy, hope, resilience, and optimism, can be included in the POB field. Their combination is known as positive psychological capital or PsyCap (Luthans, Avey, Avolio, Norman, \& Combs, 2006). PsyCap is defined as "an individual's positive psychological state of development and is characterized by: (a) having confidence (selfefficacy) to take on and put in the necessary effort to succeed at challenging tasks; (b) making a positive attribution (optimism) about succeeding now and in the future; (c) persevering towards goals and, when necessary, redirecting paths to goals (hope) in order to succeed; and (d) when beset by problems and adversity, sustaining and bouncing back and even beyond (resiliency) to attain success" (Luthans et al., 2007, p. 3).

Although numerous empirical studies revealed the conceptual independence and discriminant validity of the elements of PsyCap, Luthans and colleagues (2007) have proposed a link between these components (i.e., a high order factor) that represents the common variance between self-efficacy, optimism, resilience, and hope. The components of PsyCap interact synergistically (Luthans et al., 2015). As a second order factor, PsyCap is considered as a positive assessment of physical and personal resources availability, the likelihood of reaching success through personal effort, achievement striving, and perseverance in a particular situation (Luthans \& Youssef, 2007). The communality of the elements of PsyCap is also indicated by the psychological resources theory (Hobfoll, 2002) and the concept of core confidence (Stajkovic, 2006). In addition to these conceptual arguments for the integration of selfefficacy, hope, resilience, and optimism into a higher order factor, be it called psychological capital or other, Luthans and colleagues (2015) showed that compared to its components, PsyCap as a second order factor is a better predictor of employees' job performance rated by their supervisors. PsyCap has three essential attributes that permit its differentiation from other constructs with a positive approach: (a) individual level of analysis; (b) state-like nature; and (c) ability to predict relevant aspects for organizations (Luthans \& Youssef, 2007). Given the purpose of this study, we will focus on the latter aspect. Recent meta-analyses and reviews found that PsyCap is positively related to desired employees' attitudes, behaviors, and performance (Avey, Reichard, Luthans, \& Mhatre, 2011) and negatively related to undesired attitudes, behaviors, and performance in the workplace (Rus \& Jesus, 2010). Although there is a lack of studies on the relationship between PsyCap and teacher motivation, a study of Siu, 
Bakker, and Jiang (2014), conducted in an academic context, underlined that individuals with high PsyCap are: (a) able to establish difficult and specific goals; (b) intrinsically motivated; (c) better performers; and (d) more engaged.

\section{Review Objectives}

The present literature review intended to examine the studies that related work satisfaction and PsyCap with teacher motivation, given that both constructs play a crucial role on the motivation of teachers. We expected this review to be useful for the development of the research on teacher motivation, because it evaluated the relationship between two of the most analyzed variables in the organizational area (i.e., work motivation and satisfaction) and considered an individual variable with positive nature (i.e., PsyCap) instead of the most commonly used individual variables that refer to malaise factors (e.g., distress and burnout).

\section{Method}

The selected studies should have been published between January 1990 and September 2014. This period was chosen according to the assumptions of Jesus (2003), this author argued that the flow of empirical studies on teacher motivation significantly increased during the 1990 s ( $20^{\text {th }}$ century). Nevertheless, it should be noted that one of the addressed concepts (PsyCap) has been developed in the first decade of 2000, however work satisfaction has a wider history and is one of the most studied variables in the context of teacher motivation. Thus, it was expected that the number of studies on work satisfaction was higher comparatively to PsyCap. In order to identify the relevant documents for this review, an electronic search on the following electronic databases was conducted: (a) Web of Science (Web of Knowledge); (b) PsychInfo, Psychology and Behavioral Sciences, and Education Resources Information Center (ERIC) (EBSCOhost); (c) ProQuest; (d) ScienceDirect; and (e) Wiley Online Library. In the databases ERIC, Psychology and Behavioral Sciences, and ProQuest the month and year defined as time limit for the search (i.e., January 1990 and September 2014) were included in the respective fields. In Web of Science, PsychInfo, ScienceDirect, and Wiley Online Library only the years of publication (i.e., 1990-2014) were included in the search field. The keywords used were teacher motivation, work satisfaction or job satisfaction, and positive psychological capital, psychological capital, or psycap. The keyword teacher motivation was included in all the searches being combined with the other keywords 
(e.g., teacher motivation and positive psychological capital or psychological capital or psycap, and teacher motivation and job satisfaction or work satisfaction).

Five inclusion criteria were defined: (a) empirical paper; (b) publication in a peerreviewed journal between 1990 and 2014; (c) relate teacher motivation with work satisfaction and PsyCap; and (d) Portuguese, English, Spanish, and German as publication languages. The studies that failed to meet these criteria were excluded from the sample. The selection of studies was conducted by two researchers following a four-stage process: (a) respect for the inclusion criteria; (b) analysis of the studies title and abstract; (c) assessment of the full text; and (d) search for duplicates. In situations of uncertainty, two independent reviewers were consulted. When a study was excluded from the review, the decision about the exclusion was documented. The studies selected are marked with an asterisk $(*)$ in the references section. The reviewers achieved a 97\% agreement level. The collected documents were evaluated descriptively regarding the: (a) year of publication; (b) author(s); (c) type of methodology employed (i.e., quantitative, qualitative, or mixed); (c) sample characterization (i.e., number of participants, gender, and type of education provided); (d) type of instrument; and (e) number of studies per construct. Subsequently, the studies were assessed regarding the examined concept (i.e., work satisfaction or PsyCap) and a synthesis of the main results was performed.

\section{Results}

The search process resulted in 78 studies. From these, $43(55.13 \%)$ respected the inclusion criteria and were reviewed. 2012 was the year with the highest number of studies $(n=$ 7; 16.28\%), followed by: (a) 2010, 2011, and 2013 ( $n=5$; 11.63\%); (b) 2009 and 2014 ( $n=3$; 6.98\%); (c) 2000, 2001, 2002, and 2006 ( $n=2$; 4.65\%); and (d) 1992, 1994, 1996, 1998, 1999, 2005, and $2007(n=1 ; 2.33 \%)$. There was no record of studies published in the years: (a) 1990; (b) 1991; (c) 1993; (d) 1995; (e) 1997; (f) 2003; (g) 2004; and (h) 2008. At the methodological design level, the majority of studies presented a quantitative approach $(n=$ $40 ; 93.02 \%)$ followed by the works with a mixed approach $(n=3 ; 6.98 \%)$, in contrast there was no record of studies with a qualitative approach. The use of mixed samples (i.e., men and women teachers) was the most identified situation $(n=41 ; 95.35 \%)$, however works composed solely by women teachers were also observed $(n=2 ; 4.65 \%)$. Regarding the teaching level, studies composed by teachers from different levels $(n=22 ; 51.16 \%)$ were more common than those with teachers from the same level $(n=21 ; 48.84 \%)$. 
Relatively to the instruments used, it was observed that self-report questionnaires ( $n=$ $43 ; 89.59 \%)$ were the measure most frequently applied, studies that used interviews $(n=3$; $6.25 \%)$, focus groups $(n=1 ; 2.08 \%)$, and observations $(n=1 ; 2.08 \%)$ were also registered. The number of instruments exceeds the total of studies because some of the analyzed documents presented more than one type of measure. Concerning the number of participants in the studies, it was verified an average value of approximately $675(M=675.28 ; S D=727.699)$. Taking into account that some studies had a high number of participants, it was also calculated the median value: 400 . The estimation of this value was conducted, since the studies with larger samples could have influenced the mean value obtained. The relationship between teacher motivation and work satisfaction was examined in 42 studies (97.67\%). In the case of PsyCap, this construct only possessed one study $(2.33 \%)$ with teacher motivation.

A synthesis of the main results of each study, as well as data related with the methodological approach used, name of the authors, year of publication, number of participants, type of instrument administered, and education level of the samples are presented in Table 1.

Table 1. Synthesis of the key findings of the sample of studies $(N=43)$

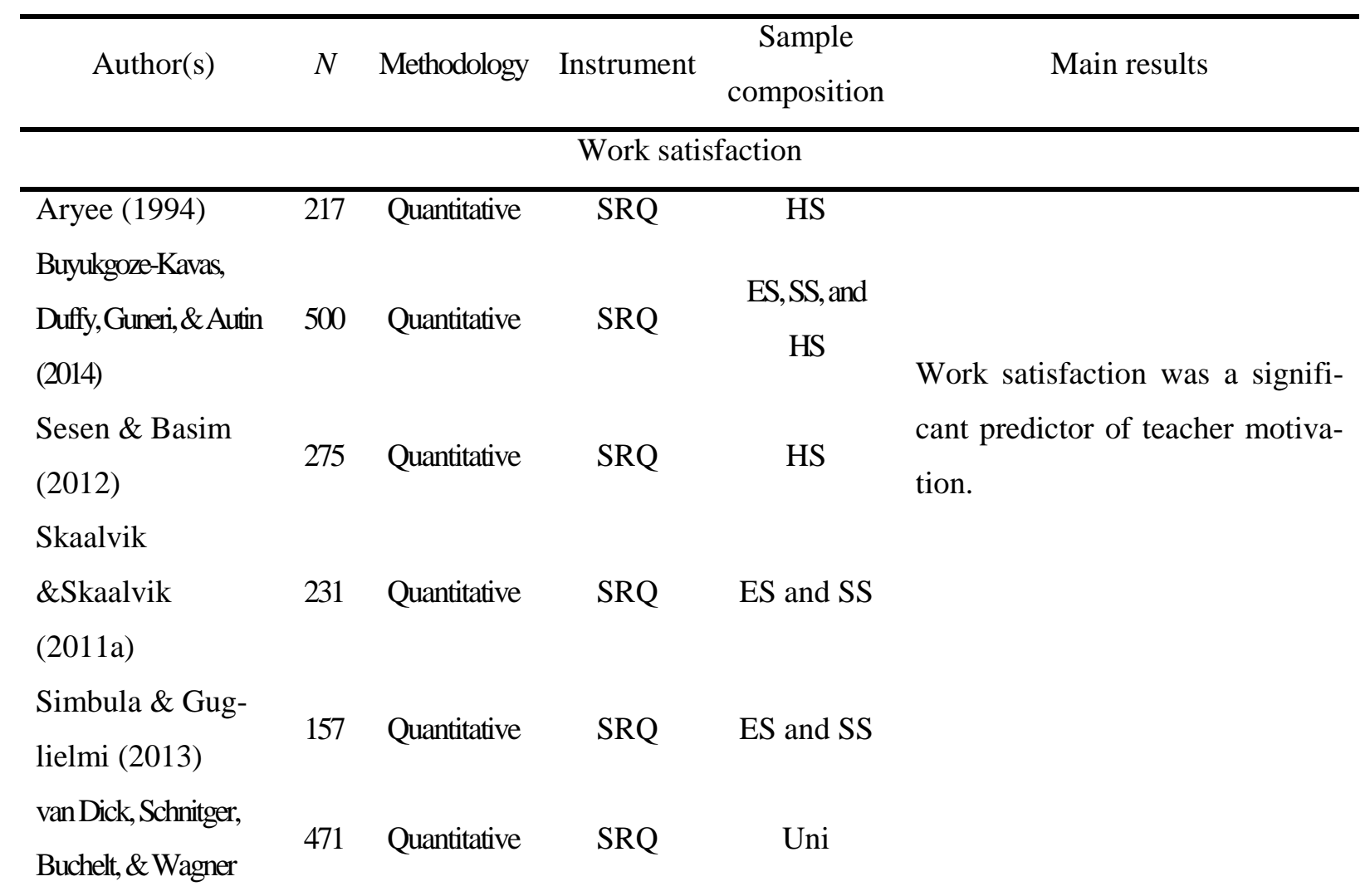


(2011)

Wu \& Short (1996)
$\mathrm{ES}, \mathrm{SS}$, and

HS

Caprara, Barbaranelli,

Steca, \&
(2006)

Ciftci, Ozgun, \&

Erden (2011)

140 Quantitative SRQ

PS

Di Fabio, Majer,

\& Taralla (2006)

328 Quantitative SRQ

HS

Work satisfaction and teacher motivation established a positive and statistically significant corre-

Federici (2013) 1818 Quantitative $\quad$ SRQ

Federici \&

Skaalvik (2012)

1818 Quantitative SRQ ES and SS

Fernet, Austin, \&

Vallerand (2012)

586 Quantitative SRQ ES and HS

Karabiyik \&

Korumaz (2014)

83 Quantitative SRQ

Karsh \& Iskender

(2009)

400 Quantitative SRQ

ES, SS, and

HS

ES and SS lation. The magnitude of the correlation coefficients varied between moderate and strong. In a specific case (Fernet et al., 2012) it was observed that work satisfaction was negatively corre$\mathrm{ES}, \mathrm{SS}$, and motivation.

HS

Klassen \& Chiu

(2010)

1430 Quantitative

SRQ

ES and HS

Klassen et al.

(2012)

853 Quantitative SRQ

ES, SS, and

HS

Papaioannou \&

Christodoulidis

(2007)

573 Quantitative

SRQ

ES, SS, HS, and Uni

Salehi \&

Gholtash (2011)

341 Quantitative SRQ

Uni

Skaalvik \&

Skaalvik (2013)

2569 Quantitative

SRQ

ES and SS

Skaalvik \&

Skaalvik (2014)

2569 Quantitative

SRQ

ES and SS

Stan (2013)

106 Quantitative

SRQ

PS and ES

Skaalvik \&

Skaalvik (2011b)
2569 Quantitative

SRQ
Work satisfaction was negatively

ES and SS correlated with teacher demotivation. The correlation coefficient 


\begin{tabular}{|c|c|c|c|c|c|}
\hline & & & & & $\begin{array}{l}\text { obtained was statistically signifi- } \\
\text { cant. }\end{array}$ \\
\hline Mertler (2012) & 710 & Quantitative & SRQ & SS and HS & Teachers work satisfaction varies \\
\hline $\begin{array}{l}\text { Scott, Cox, \& } \\
\text { Dinham (1999) }\end{array}$ & 609 & Quantitative & SRQ & ES & $\begin{array}{l}\text { according to: (a) gender (Mertler, } \\
2012) ; \quad \text { (b) career position }\end{array}$ \\
\hline $\begin{array}{l}\text { Klassen et al. } \\
\text { (2013) }\end{array}$ & 1187 & Quantitative & SRQ & ES and SS & $\begin{array}{l}\text { (Mertler, 2012; Scott et al., } \\
\text { 1999); (c) school's geographic }\end{array}$ \\
\hline $\begin{array}{l}\text { Billingsley \& } \\
\text { Cross (1992) }\end{array}$ & 902 & Quantitative & SRQ & SE & $\begin{array}{l}\text { location (Klassen et al., 2010; } \\
\text { Klassen et al., 2013; Mertler, }\end{array}$ \\
\hline $\begin{array}{l}\text { Klassen, Usher, \& } \\
\text { Bong (2010) }\end{array}$ & 500 & Quantitative & SRQ & ES and SS & $\begin{array}{l}\text { 2012); (d) type of education pro- } \\
\text { vided (i.e., regular vs. special) }\end{array}$ \\
\hline $\begin{array}{l}\text { Griva, Panitsidou, \& } \\
\text { Chostelidou(2012) }\end{array}$ & 120 & Mixed & $\begin{array}{c}\text { SRQ, Int, } \\
\text { Obs, andFG }\end{array}$ & ES and SS & $\begin{array}{l}\text { (Billingsley \& Cross, 1992); (e) } \\
\text { subject taught (Griva et al., }\end{array}$ \\
\hline Poblete (2009) & 539 & Quantitative & SRQ & ES & 2012); and (f) type of educational \\
\hline $\begin{array}{l}\text { Pifczyk \& Klein- } \\
\text { beck (2000) }\end{array}$ & 48 & Quantitative & SRQ & PS & $\begin{array}{l}\text { establishment (public vs. private) } \\
\text { (Poblete, 2009; Pifczyk \& Klein- } \\
\text { beck, 2000; Scott et al., 1999) } \\
\text { which influences the relationship } \\
\text { established with teacher motiva- } \\
\text { tion. }\end{array}$ \\
\hline $\begin{array}{l}\text { Schonfeld (2000, } \\
\text { 2001) }\end{array}$ & 184 & Quantitative & SRQ & PS and ES & $\begin{array}{l}\text { Malaise factors, such as depres- } \\
\text { sion and distress, influenced the } \\
\text { relationship between work satis- } \\
\text { faction and teacher motivation. }\end{array}$ \\
\hline Griffin (2010) & 168 & Quantitative & SRQ & $\begin{array}{c}\text { ES, SS, and } \\
\text { HS }\end{array}$ & $\begin{array}{l}\text { Dimensions of work satisfaction } \\
\text { (a) work conditions (Griffin, }\end{array}$ \\
\hline $\begin{array}{l}\text { Wagner \& French } \\
\text { (2010) }\end{array}$ & 77 & Mixed & $\begin{array}{l}\text { SRQ and } \\
\text { Int }\end{array}$ & PS & $\begin{array}{l}\text { 2010); (b) salary (Griffin, 2010); } \\
\text { (c) job security (Griffin, 2010); }\end{array}$ \\
\hline Canrinus, Helms- & & & & & (d) supervisor support (Wagner \\
\hline $\begin{array}{l}\text { Lorenz, Beijaard, } \\
\text { Buitink, \& Hofman } \\
\text { (2012) }\end{array}$ & 1214 & Quantitative & SRQ & SS & $\begin{array}{l}\text { \& French, 2010); and (e) rela- } \\
\text { tionship with students and col- } \\
\text { leagues (Canrinus et al., 2012; }\end{array}$ \\
\hline Karavas (2010) & 224 & Quantitative & SRQ & SS & Griffin, 2010; Karavas, 2010; \\
\hline Shann (1998) & 92 & Mixed & $\begin{array}{l}\text { SRQ and } \\
\text { Int }\end{array}$ & SS & $\begin{array}{l}\text { Shann, 1998) affected teacher } \\
\text { motivation. Two of these dimen- } \\
\text { sions, salary incentives and rela- }\end{array}$ \\
\hline
\end{tabular}


tionship with students, did not improve the motivation of teachers (salary incentives) or contributed to their demotivation (student misbehavior) (Canrinus et al,. 2012; Shann, 1998).

\begin{tabular}{|c|c|c|c|c|c|}
\hline Bentea \& & & & & & \\
\hline $\begin{array}{l}\text { Anghelache } \\
\text { (2012) }\end{array}$ & 122 & Quantitative & SRQ & $\begin{array}{c}\text { ES, SS, and } \\
\text { HS }\end{array}$ & $\begin{array}{l}\text { Teacher motivation predicted } \\
\text { work satisfaction and not the }\end{array}$ \\
\hline $\begin{array}{l}\text { Duffy \& Lent } \\
\text { (2009) }\end{array}$ & 366 & Quantitative & SRQ & $\begin{array}{c}\text { ES, SS, and } \\
\text { HS }\end{array}$ & reverse. \\
\hline $\begin{array}{l}\text { Jesus \& Lens } \\
(2005)\end{array}$ & 258 & Quantitative & SRQ & ES and SS & \\
\hline $\begin{array}{l}\text { Martin \& Stef- } \\
\text { fgen }(2002)\end{array}$ & 402 & Quantitative & SRQ & ES & \\
\hline \multicolumn{6}{|c|}{ PsyCap } \\
\hline $\begin{array}{l}\text { Vink, Ouweneel, \& } \\
\text { LeBlanc (2011) }\end{array}$ & 301 & Quantitative & SRQ & Uni & $\begin{array}{l}\text { Positive psychological capital } \\
\text { was significantly associated with } \\
\text { teacher motivation. }\end{array}$ \\
\hline
\end{tabular}

Note. For each study were presented the author(s), year of publication, number of participants $(N)$, methodology employed, type of instrument used, and sample composition. As some studies possessed similar results, in those situations the main results were aggregated. SRQ: Self-report questionnaire; Int: Interview; Obs: Observation; FG: Focus group; PS: Pre-school teachers; ES: Elementary school teachers; SS: Secondary school teachers; HS: High school teachers; Uni: University teachers; SE: Special education teachers.

\section{Discussion}

The objective of this review was to examine the studies that related work satisfaction and PsyCap with teacher motivation. In educational establishments, teacher motivation emerges as a vital construct because of the teachers' role in classroom and school functioning (Jesus \& Lens, 2005). Thus, it is important to evaluate how teacher motivation and work satisfaction are related, given the close relationship between both concepts. In the case of PsyCap, this individual variable was chosen since it focuses on individual strengths in contrast with the majority of the individual variables studied with teacher motivation, which refer to malaise factors (e.g., Aloe et al., 2014). 
The publication flow was higher between 2010 and 2014 (58.15\%) which indicates an increase in the research on this theme over the past years. In the majority of studies was observed a preponderance of quantitative methodologies (93.02\%) and self-report questionnaires (89.59\%), situation that might have occurred because quantitative methodologies facilitate the access to larger samples and self-report questionnaires enable the evaluation of several variables simultaneously (Gelo, Braakman, \& Benetka, 2008). The combination of these aspects allows the gathering of information regarding an individual's work environment, providing a complete and accurate picture of that context. The number of studies that related work satisfaction with teacher motivation underlined the importance of this relationship. In opposition, the lack of studies that associated PsyCap and teacher motivation points to the need of further research, because greater PsyCap may increase professional motivation, since this concept possesses a motivational nature.

The correlation coefficients between teacher motivation and work satisfaction emphasized the importance of these variables in educational context. Motivated and satisfied teachers have better teaching quality and motivate their students (Vieira \& Jesus, 2007). Some studies demonstrated that work satisfaction affects teacher motivation and vice-versa, which may indicate a bidirectional relationship (Judge \& Kammeyer-Mueller, 2012). Fernet and colleagues (2012) observed that work satisfaction was negatively correlated with teacher controlled motivation, this might be explained because controlled motivation is associated with a sense of obligation to engage in professional activities which is translated into reduced autonomy and performance (Gagné \& Deci, 2005). Aspects, such as the type of educational establishment (public vs. private), malaise factors, salary incentives, socio-demographic variables, and students' behavior are responsible for variations in this relationship. Liu and Meyer (2005) observed that teachers from private schools reported higher satisfaction than those from public schools. Taking into account the association between work satisfaction and teacher motivation, it can be stated that private school teachers are more satisfied and motivated. Work-related malaise factors contributed to an increase in turnover rates, which can be considered as an indicator of demotivation (Yu et al., 2014). Past studies (e.g., Jesus et al., 2011; Lambert \& McCarthy, 2006; OECD, 2005) emphasized that turnover rates in teaching have significantly grown in the last years, becoming a relevant problem. The impact of salary incentives on satisfaction and motivation is unclear, as shown by the analyzed studies. In the literature, there are also contradictory findings. On the one hand, there are studies (e.g., Green 
\& Heywood, 2008) that indicate that salary incentives reduce work satisfaction and motivation. On the other hand, other studies (e.g., Marsden, French, \& Kubo, 2001) demonstrated that salary incentives contribute to professional demotivation. In the case of sociodemographic variables, Glisson and Durick (2008) stressed that in teaching these variables significantly influence work satisfaction. Nevertheless, their impact is limited. Lastly, student misbehavior is a major source of teacher dissatisfaction and demotivation being responsible for the appearance of malaise factors (Aloe et al., 2014).

Vink and colleagues (2011) registered that PsyCap presented benefits for teacher motivation. This situation might point to the importance of developing self-efficacy, optimism, resilience, and hope in teachers in order to improve their motivation, which will influence the quality of teaching and student motivation, and reduce malaise factors and turnover rates.

Our review provided a synthesis of the studies that related teacher motivation with work satisfaction and PsyCap. In the case of the relationship between work motivation and satisfaction, it was possible to aggregate several studies that assessed these variables obtaining a clear image of the state-of-the-art. A recent bibliometric study (Viseu, Jesus, QuevedoBlasco, Rus, \& Canavarro, 2015) observed that work satisfaction was the most evaluated construct with teacher motivation, underlining its importance in this field. In turn, the lack of studies that related teacher motivation and PsyCap is a major gap. According to the POB criteria, job performance and satisfaction were the main outcomes to be studied. With the growing interest of studying PsyCap, the attention was focused on the desirable and undesirable attitudes, and behaviors. PsyCap includes a motivational propensity and it was less of interest to study associations between various motivational variables than studying relationships between motivational variables and work outcomes.

Regarding the addressed variables (work satisfaction and PsyCap), it is crucial to emphasize how they can be improved in order to increase teacher motivation. The satisfaction of teachers may developed through the creation of social support networks between colleagues (e.g., for sharing work experiences) and the existence of an effective leadership able to provide constructive feedback (Hongying, 2007; Judge \& Kammeyer-Mueller, 2012). Likewise, other aspects may facilitate teacher satisfaction, for example interpersonal relationships may be fostered through intervention programs (e.g., Leiter, Laschinger, Day, \& Gilin-Oore, 2012), enhancement of professional development opportunities (e.g., teachers with better a 
performance may have the possibility to gain access to personal and professional development programs), create better work conditions (e.g., appropriate teaching materials), greater autonomy in the tasks performed, and reduction of work-related stressors (e.g., work schedule and workload) (Hongying, 2007). These measures will improve the satisfaction and motivation of teachers, and contribute to a decrease in turnover rates, fundamental elements to promote school success (Hongying, 2007; Judge \& Kammeyer-Mueller, 2012). Avey (2014) proposed a set of actions to increase workers PsyCap and organizational performance. In terms of selection, teachers may be selected in terms of their PsyCap levels (Avey, 2014). In addition, school principals may receive leadership training, as there are types of leadership (e.g., authentic leadership) that promote the psychological skills of employees, and job redesign may improve PsyCap. (Avey, 2014). Moreover, intervention programs have been created seeking to develop the dimensions that compose this concept (Luthans et al., 2006; Luthans, Avey, \& Patera, 2008; Luthans et al., 2015).

This review possesses some limitations. For example, other positive psychology variables (e.g., psychological and subjective well-being, and creativity) could have been included due to the need of improving teachers' mental health. Furthermore, the inclusion of organizational variables (e.g., organizational culture and justice) could have been considered, in order to understand how they relate to teacher motivation. Thus, the addition of the abovementioned variables, along with work satisfaction and PsyCap, would be beneficial to analyze which of them are more studied in the teacher motivation area. Thereby, future reviews may consider this suggestion, which will make possible an assessment of the relationship between these variables and teacher motivation, and will provide an accurate picture of the aspects that influence the motivation of these professionals. Also, future studies may develop an integrative model for the evaluation of teacher motivation similar to the work of Jesus and Lens (2005). This model should integrate different types of variables, such as organizational and individual (e.g., organizational culture and justice, and creativity). The assessment of these variables could be helpful to understand how they are linked to teacher motivation and to develop possible solutions. These solutions may be focused on intervention programs based on PsyCap and stress management (Jesus, Miguel-Tobal, Rus, Viseu, \& Gamboa, 2014), because they will contribute to an increase of professional motivation, as well as a decrease on distress, burnout, and depression. This situation will benefit school and classroom functioning, namely in the implementation of educational policies, quality of teaching, and student motivation. 
In sum, it is important that educational leaders are aware of the importance of teacher motivation, because teachers are one of the most important pillars in the entire educational system. As stated above, teachers play an important role on student motivation, but also in the quality of teaching. Moreover, teachers are key actors in the implementation of educational reforms. Thus, only with motivated teachers will be possible to keep students motivated and deliver a quality education. For this to happen, and taking into account the reviewed studies, school leaders must invest in the work conditions of teachers, as the work satisfaction and motivation of these professionals are closely linked. Furthermore, although the number of studies between PsyCap and teacher motivation is reduced, schools should invest in the promotion of this construct, since it presents a motivational nature. Consequently, when working on the psychological strengths of teachers schools will be contributing to their motivation.

\section{Acknowledgments}

The Portuguese Foundation for Science and Technology (FCT) financed this project through a PhD research grant (SFRH/BD/89588/2012) awarded to the first author.

\section{References}

Addison, R., \& Brundrett, M. (2008). Motivation and demotivation of teachers in primary schools: The challenge of change. Education 3-13: International Journal of Primary, Elementary and Early Years Education, 36, 79-94. doi: $10.1080 / 030004270701733254$

Aloe, A., Shisler, S., Norris, B., Nickerson, A., \& Rinker, T. (2014). A multivariate metaanalysis of student misbehavior and teacher burnout. Educational Research Review, 12, 30-44. doi: 10.1016/j.edurev.2014.05.003

*Aryee, S. (1994). Job involvement: An analysis of its determinants among male and female teachers. Canadian Journal of Administrative Sciences/Revue Canadienne des Sciences de l'Administration, 11, 320-330. doi: 10.1111/j.1936-4490.1994.tb00071.x

Avey, J. (2014). The left side of psychological capital: New evidence on the antecedents of PsyCap. Journal of Leadership \& Organizational Studies, 21, 141-149. doi: $10.1177 / 1548051813515516$ 
Avey, J., Reichard, R., Luthans, F., \& Mhatre, K. (2011). Meta-analysis of the impact of positive psychological capital on employee attitudes, behaviors, and performance. Human Resource Development Quarterly, 22, 127-152. doi: 10.1002.hrdq.20070

Bakker, A., \& Schaufeli, W. (2008). Positive organizational behavior: Engaged employees in flourishing organizations [Editorial]. Journal of Organizational Behavior, 29, 147154. doi: 10.1002/job.515

*Bentea, C., \& Anghelache, V. (2012). Teachers' motivation and satisfaction for professional activity. Procedia - Social and Behavioral Sciences, 33, 563-567. doi: 10.1016/j.sbspro.2012.01.184

*Billingsley, B., \& Cross, L. (1992). Predictors of commitment, job satisfaction, and intent to stay in teaching: A comparison of general and special educators. The Journal of Special Education, 25, 453-471. doi: 10.1177/002246699202500404

*Buyukgoze-Kavas, A., Duffy, R., Guneri, O., \& Autin, K. (2014). Job satisfaction among Turkish teachers: Exploring differences by school level. Journal of Career Assessment, 22, 261-273. doi: 10.1177/1069072713493980

*Canrinus, E., Helms-Lorenz, M., Beijaard, D., Buitink, J., \& Hofman, A. (2012). Selfefficacy, job satisfaction, motivation and commitment: Exploring the relationships between indicators of teachers' professional identity. European Journal of Psychology of Education, 27, 115-132. doi: 10.1007/s10212-011-0069-2

Cardelle-Elawar, M., Irwin, L., \& Lizarraga, M. (2007). A cross cultural analysis of motivational factors that influence teacher identity. Electronic Journal of Research in Educational Psychology, 5(3), 565-592.

*Caprara, G., Barbaranelli, C., Steca, P., \& Malone, P. (2006). Teachers' self-efficacy beliefs and students' academic achievement: A study at the school level. Journal of School Psychology, 44, 473-490. doi: 10.1016/j.jsp.2006.09.001

*Ciftci, M., Ozgun, O., \& Erden, S. (2011). Self-efficacy and satisfaction of pre-service early childhood teachers as a function of perceived needs and experiences. Procedia - Social and Behavioral Sciences, 15, 539-544. doi: 10.1016/j.sbspro.2011.03.138

Dalal, R., Baysing, M., Brummel, B., \& LeBreton, J. (2012). The relative importance of employee engagement, other job attitudes, and trait affect as predictors of job performance. Journal of Applied Social Psychology, 42(S1), E295-E325. doi: 10.1111/j.1559-1816.2012.01017.x 
*Di Fabio, A., Majer, V., \& Taralla, B. (2006). Correlations of teacher self-efficacy: Personal characteristics and attitude toward the job. Psychologie du travail et des organisations, 12, 263-277. doi: 10.1016/j.pto.2006.07.001

*Duffy, R., \& Lent, R. (2009). Test of a social cognitive model of work satisfaction in teachers. Journal of Vocational Behavior, 75, 212-223. doi: 10.1016/j.jvb.2009.06.001

*Federici, R. (2013). Principals' self-efficacy: Relations with job autonomy, job satisfaction, and contextual constraints. European Journal of Psychology of Education, 28, 73-86. doi: 10.1007/s10212-011-0102-5

*Federici, R., \& Skaalvik, E. (2012). Principal self-efficacy: Relations with burnout, job satisfaction, and motivation to quit. Social Psychology of Education, 15, 295-320. doi: $10.1007 / \mathrm{s} 11218-012-9183-5$

*Fernet, C., Austin, S., \& Vallerand, R. (2012). The effects of work motivation on employee exhaustion and commitment: An extension of the JD-R model. Work \& Stress: An International Journal of Work, Health \& Organisations, 26, 213-229. doi: $10.1080 / 02678373.2012 .713202$

Gagné, M., \& Deci, E. (2005). Self-determination theory and work motivation. Journal of Organizational Behavior, 26, 331-362. doi: 10.1002/job.332

Gelo, O., Braakman, D., \& Benetka, G. (2008). Quantitative and qualitative research: Beyond the debate. Integrative Psychological and Behavioral Science, 42, 266-290. doi: $10.1007 / \mathrm{s} 12124-008-9078-3$

Glisson, C., \& Durick, M. (1988). Predictors of job satisfaction and organizational commitment in human service organizations. Administrative Quarterly, 33, 61-81. doi: $10.2307 / 2392855$

Gomes, D., \& Borba, D. (2011). Motivação no trabalho [Work motivation]. In D. Gomes (Coord.), Psicologia das organizações, do trabalho e dos recursos humanos [Psychology of the organizations, work, and human resources] (pp. 243-319). Coimbra, Portugal: Imprensa da Universidade de Coimbra.

Green, C., \& Heywood, J. (2008). Does performance pay increase job satisfaction?. Economica, 75, 710-728. doi: 10.1111/j.1468-0335.2007.00649.x

*Griffin, D. (2010). A survey of Bahamian and Jamaican teachers' level of motivation and job satisfaction. Journal of Invitational Theory and Practice, 16, 56-76.

*Griva, E., Panitsidou, E., \& Chostelidou, D. (2012). Identifying factors of job motivation and satisfaction of foreign language teachers: Research project design. Procedia - Social and Behavioral Sciences, 46, 543-547. doi: 10.1016/j.sbspro.2012.05.157 
Hobfoll, S. (2002). Social and psychological resources and adaptation. Review of General Psychology, 6, 307-324. doi: 10.1037/1089-2680.6.4.307

Hongying, S. (2007). Literature review of teacher job satisfaction. Chinese Education and Society, 40(5), 11-16. doi: 10.2753/CED1061-1932400502

Jesus, S. N. (1996). A motivação para a profissão docente [Teacher motivation]. Aveiro, Portugal: Estante Editora.

Jesus, S. N. (2003). La motivación de los profesores: Una revisión de la literatura [Teacher motivation: A literature review]. In D. García-Villamisar \& T. Freixas Guinjoan (Eds.), El estrés del profesorado [Teachers' stress] (pp. 119-139). Valencia, España: Promolibro.

*Jesus, S. N., \& Lens, W. (2005). An integrated model for the study of teacher motivation. Applied Psychology: An International Review, 54, 119-134. doi: 10.1111/j.14640597.2005.00199.x

Jesus, S. N., Mosquera, J., Stobaus, C., Sampaio, A., Rezende, M., \& Mascarenhas, S. (2011). Avaliação da motivação e do bem/mal-estar dos professores: Estudo comparativo entre Portugal e o Brasil [Evaluation of the motivation and well/ill-being of teachers: Comparative study between Portugal and Brazil]. Amazônica: Revista de Psicopedagogia, Psicologia Escolar e Educação, 7(2), 7-18.

Jesus, S. N., Miguel-Tobal, J., Rus, C., Viseu, J., \& Gamboa, V. (2014). Evaluating the effectiveness of a stress management training on teachers and physicians' stress related outcomes. Clínica y Salud, 25, 111-115. doi: 10.1016/j.clysa.2014.06.004

Judge, T., \& Kammeyer-Mueller, J. (2012). Job attitudes. Annual Review of Psychology, 63, 341-367. doi: 10.1146/ annurev-psych-120710-100511

*Karabiyik, B., \& Korumaz, M. (2014). Relationship between teachers' self-efficacy perceptions and job satisfaction level. Procedia - Social and Behavioral Sciences, 116, 826830. doi: 10.1016/j.sbspro.2014.01.305

*Karavas, E. (2010). How satisfied are Greek EFL teachers with their work? Investigating the motivation and job satisfaction levels of Greek EFL teachers. Porta Linguarum, 14, 59-78.

*Karsh, M., \& Iskender, H. (2009). To examine the effect of the motivation provided by the administration on the job satisfaction of teachers and their institutional commitment. Procedia - Social and Behavioral Sciences, 1, 2252-2257. doi: 10.1016/j.sbspro.2009.01.396 
*Klassen, R., Aldhafri, S., Mansfield, C., Purwanto, E., Siu, A., Wong, M., \& WoodsMcConney, A. (2012). Teachers' engagement at work: An international validation study. The Journal of Experimental Education, 80, 317-337. doi: 10.1080/0220973.2012.678409

*Klassen, R., \& Chiu, M. (2010). Effects on teachers' self-efficacy and job satisfaction: Teacher gender, years of experience, and job stress. Journal of Educational Psychology, 102, 741-756. doi: 10.1037/a0019237

*Klassen, R., Wilson, E., Siu, A., Hannok, W., Wong, M., Wongsri, N.,... Jansem, A. (2013). Preservice teachers' work stress, self-efficacy, and occupational commitment in four countries. European Journal of Psychology of Education, 28, 1289-1309. doi: $10.1007 / \mathrm{s} 10212-012-0166-\mathrm{x}$

*Klassen, R., Usher, E., \& Bong, M. (2010). Teachers' collective self-efficacy, job satisfaction, and job stress in cross-cultural context. The Journal of Experimental Education, 78, 464-486. doi: 10.1080/00220970903292975

Lambert, R., \& McCarthy, C. (Eds.). (2006). Understanding teacher stress in an age of accountability. Greenwich, CT: Age Publishing.

Larson, M., \& Luthans, F. (2006). Potential added value of psychological capital in predicting work attitudes. Journal of Leadership \& Organizational Studies, 13, 75-92. doi: $10.1177 / 10717919070130020601$

Leiter, M., Laschinger, H., Day, A., \& Gilin-Oore, D. (2011). The impact of civility interventions on employee social behavior, distress, and attitudes. Journal of Applied Psychology, 96, 1258-1274. doi: 10.1037/a0024442

Liu, X., \& Meyer, J. (2005). Teachers' perceptions of their jobs: A multilevel analysis of the teacher follow-up survey for 1994-1995. Teachers College Record, 107(5), 985-1003.

Luthans, F., Avey, J., Avolio, B., Norman, S., \& Combs, G. (2006). Psychological capital development: Toward a micro-intervention. Journal of Organizational Behaviour, 27, 387-393. doi: 10.1002/job.373

Luthans, F., Avey, J., \& Patera, J. (2008). Experimental analysis of a web-based training intervention to develop positive psychological capital. Academy of Management Learning \& Education, 7, 209-221. doi:10.5465/AMLE.2008.32712618

Luthans, F., \& Youssef, C. (2007). Emerging positive organizational behavior. Journal of Management, 33, 321-349. doi: 10.1177/0149206307300814

Luthans, F., Youssef, C., \& Avolio, B. (2007). Psychological capital: Developing the human competitive edge. New York, NY: Oxford University Press. 
Luthans, F., Youssef-Morgan, C., \& Avolio, B. (2015). Psychological capital and beyond. New York, NY: Oxford University Press.

Marsden, D., French, S., \& Kubo, K. (2001). Does performance pay de-motivate, and does it matter?. London, United Kingdom: Centre for Economic Performance.

*Martin, R., \& Steffgen, G. (2002). Effects of motivational determinants of job choice on job satisfaction among primary school teachers. Psychologie in Erziehung und Unterricht, 49, 241-249.

*Mertler, C. (2002). Job satisfaction and perception of motivation among middle and high school teachers. American Secondary Education, 31(1), 43-53.

Mueller, F., \& Hanfstingl, B. (2010). Teacher motivation [Special issue editorial]. Journal of Educational Research Online, 2(2), 5-8.

Organisation for Economic Co-operation and Development. (2005). Teachers matter: Attracting, developing and retaining effective teachers. Paris, France: OECDPublishing.

*Papaioannou, A., \& Christodoulidis, T. (2007). A measure of teachers' achievement of goals. Educational Psychology: An International Journal of Experimental Educational Psychology, 27, 349-361. doi: 10.1080/01443410601104148

*Pifczyk, A., \& Kleinbeck, U. (2000). The influence of achievement and affiliation variables on work motivation and work satisfaction in a social work environment. Zeitschrift fur Arbeits-und Organisationspsychologie, 44, 57-68. doi: 10.1026//0932-4089.44.2.57

*Poblete, G. (2009). Organizational commitment of Chilean teachers and their relationship to intention to remain in their schools. Revista Latinoamericana de Psicología, 41(3), 445-460.

Rus, C., \& Jesus, S. N. (2010). Psychological capital in organizational context: A metaanalytic study. In M. Milcu (Ed.), Modern Psychology Research: Quantitative research vs. Qualitative research? (pp. 142-151). Sibiu, Romania: Editura Universitara.

*Salehi, M., \& Gholtash, A. (2011). The relationship between job satisfaction, job burnout and organizational commitment with organizational citizenship behavior among members of faculty in the Azad University - First district branches, in order to provide the appropriate model. Procedia - Social and Behavioral Sciences, 15, 306-310. doi: 10.1016/j.sbspro.2011.03.091

Santisi, G., Magnano, P., Hichy, Z., \& Ramaci, T. (2014). Metacognitive strategies and work motivation in teachers: An empirical study. Procedia - Social and Behavioral Sciences, 116, 1227-1231. doi: 10.1016/j.sbspro.2014.01.373 
*Schonfeld, I. (2000). An updated look at depressive symptoms and job satisfaction in firstyear women teachers. Journal of Occupational and Organizational Psychology, 73, 363-371. doi: 10.1348/096317900167074

*Schonfeld, I. (2001). Stress in 1st-year women teachers: The context of social support and coping. Genetic, Social, and General Psychology Monographs, 127, 133-168.

*Scott, C., Cox, S., \& Dinham, S. (1999). The occupational motivation, satisfaction and health of English school teachers. Educational Psychology: An International Journal of Experimental Educational Psychology, 19, 287-308. doi: $10.1080 / 01443419901900304$

*Sesen, H., \& Basim, N. (2012). Impact of satisfaction and commitment on teachers' organizational citizenship. Educational Psychology: An International Journal of Experimental Educational Psychology, 32, 475-491. doi: 10.1080/01443410.2012.670900

*Shann, M. (1998). Professional commitment satisfaction among teachers in urban middle schools. The Journal of Educational Research, 92, 67-73. doi: 10.1080 .0022067980597578

*Simbula, S., \& Guglielmi, D. (2013). I am engaged, I feel good, and I got the extra-mile: Reciprocal relationships between work engagement and consequences. Journal of Work and Organizational Psychology, 29, 117-125. doi: 10.5093/tr2013a17

Siu, O., Bakker, A., \& Jiang, X. (2014). Psychological capital among university students: Relationships with study engagement and intrinsic motivation. Journal of Happiness Studies, 15, 979-994. doi: 10.1007/s10902-9459-2

*Skaalvik, E., \& Skaalvik, S. (2011a). Teachers' feeling of belonging, exhaustion, and job satisfaction: The role of goal structure and value consonance. Anxiety, Stress, \& Coping, 24, 369-385. doi: 10.1080/10615806.2010.544300

* Skaalvik, E., \& Skaalvik, S. (2011b). Teacher job satisfaction and motivation to leave the teaching profession: Relations with school context, feeling of belonging, and emotional exhaustion. Teacher and Teaching Education, 27, 1029-1038. doi: 10.1016/j.tate.2011.04.001

*Skaalvik, E., \& Skaalvik, S. (2013). Teachers' perceptions of the school goal structure: Relations with teachers' goal orientations, work engagement, and job satisfaction. International Journal of Educational Research, 62, 199-209. doi: 10.1016/j.ijer.2013.09.004

*Skaalvik, E., \& Skaalvik, S. (2014). Teacher self-efficacy and perceived autonomy: Relations with teacher engagement, job satisfaction, and emotional exhaustion. Psycholog- 
ical Reports: Employment Psychology \& Marketing, 114, 68-77. doi: 10.2466/14.02.PR0.114k14w0

Stajkovic, A. (2006). Development of a core confidence-higher order construct. Journal of Applied Psychology, 91, 1208-1224. doi: 10.1037/ /0021-9010.91.6.1208

*Stan, M. (2013). Predictors of the organizational commitment in the Romanian academic environment. Procedia - Social and Behavioral Sciences, 78, 672-676. doi: 10.1016/j.sbspro.2013.04.373

*van Dick, R., Schnitger, C., Buchelt, C., \& Wagner, U. (2001). The job diagnostic survey (JDS) for educational sector occupations: An evaluation of the model properties of the job characteristic model among teachers, university staff members, and nursery school teachers with job-specific versions of the JDS. Zeitschrift fur Arbeits-und Organisationspsychologie, 45, 74-92. doi: 10.1026//0932-4089.45.2.74

Vieira, L. S., \& Jesus, S. N. (2007). A felicidade nos professores como expressão de saúde [Teachers happiness as an expression of health]. In M. Siqueira, S. N. Jesus, \& V. Oliveira (Eds.), Psicologia da Saúde: Teoria e pesquisa [Health Psychology: Theory and research] (pp. 259-285). São Paulo, Brasil: Universidade Metodista.

*Vink, J., Ouweneel, E., \& LeBlanc, P. (2011). Psychological resources for engaged employees: Psychological capital in the job demands-resources model. Gedrag \& Organisati$e, 24(2), 101-120$.

Viseu, J., Jesus, S. N., Quevedo-Blasco, R., Rus., C., \& Canavarro, J. (2015). Teacher motivation: Bibliometric analysis of the relationship with individual and organizational variables, and work attitudes. Revista Latinoamericana de Psicología, 47(1), 58-65.

*Wagner, B., \& French, L. (2010). Motivation, work satisfaction, and teacher change among early childhood teachers. Journal of Research in Childhood Education, 24, 152-171. doi: 10.1080/02568541003635268

*Wu, V., \& Short, P. (1996). The relationship of empowerment to teacher job commitment and job satisfaction. Journal of Instructional Psychology, 23(1), 85-89.

Yu, X., Wang, P., Zhai, X., Dai, H., \& Yang, Q. (2014). The effect of work stress on job burnout among teachers: The mediating role of self-efficacy. Social Indicators Research. Advance online publication. doi: 10.1007/s11205-014-0716-5 